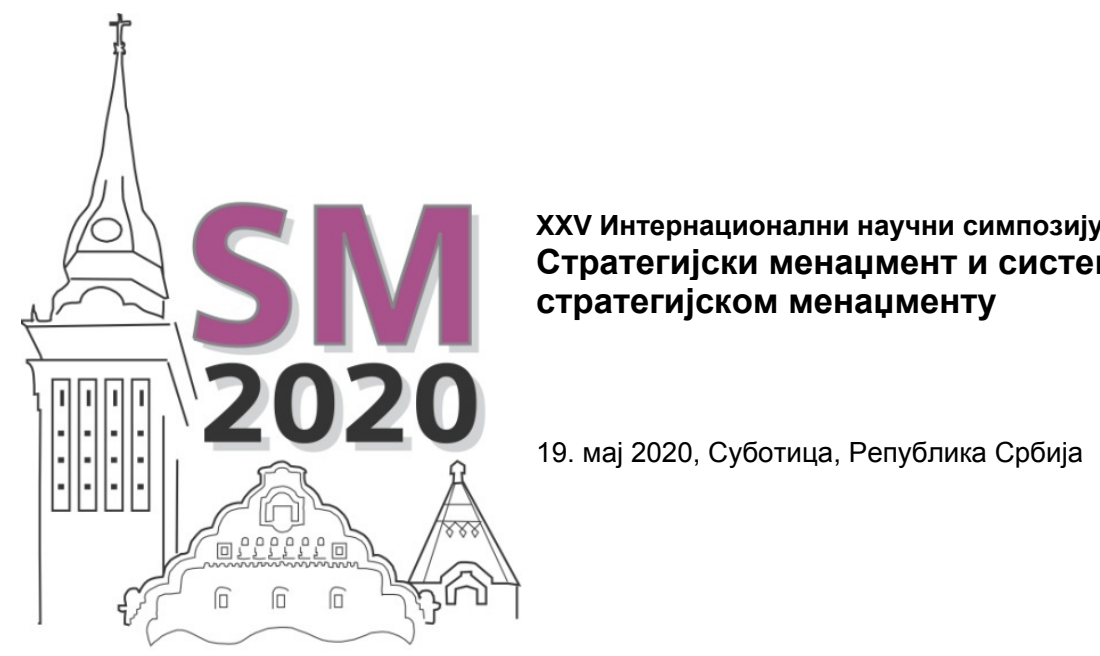

\title{
Радуле Тошовић
}

Универзитет у Београду - Рударскогеолошки факултет, Катедра економске геологије

Београд, Србија

radule.tosovic@rgf.bg.ac.rs,

toshovic@yahoo.com

\section{СТРАТЕГИЈСКА ПРИМЕНА ГЕОЛОШКО-ЕКОНОМСКОГ МОНИТОРИНГА ЗА ОБЕЗБЕЪЕЊЕ СИГУРНИЈИХ УСЛОВА ПРОИЗВОДЊЕ И ПОСЛОВАЊА ПРЕДУЗЕКА МИНЕРАЛНОГ CEKTOPA}

\begin{abstract}
Апстракт: Тржишна турболентност начина и услова пословања предузећа минералног сектора, нарочито повезаност са минералним резервама и њиховим тржишним специфичностима, захтева посебан стратегијски приступ у планирању, праћењу и реализацији пословања. Сигурност минералних резерви, њихова комерцијална и национална исплативост, односно профитабилност, као и променљивост квалитета су прилично изражени проблеми производње одређених минералних производа везаних за металичне, неметаличне и енергетске минералне сировине. Основни циљ је обезбедити услове за повећање сигурности производње минералних сировина и одговарајућих минералних производа, с обзиром на сталне промене на тржишту минералних сировина, а по основу тога и успешније пословање предузећа у минералном сектору земље, уз задржавање конкурентности. У обезбеђивању актуелних података и информација посебан значај има примена методе геолошко-економске оцене минералних резерви, са одговарајућом методском структуром фактора и показатеља оцене. Њена примена по различитим временским пресецима и променама на минералном тржишту доводи до дефинисања практично веома применљивог и корисног геолошко-економског мониторинга. Исти разрешава проблем актуелности и валидности свих производних података значајних за предметну минералну сировину и остваривање производног процеса у предузећу. Геолошко-економски мониторинг, уз примену методе компаративне анализе постаје значајан стратегијски, менаџерски и економски алат, који омогућује сигурније услове производње минералних сировина и минералних производа, као и успешнијег пословања предузећа минералног сектора.
\end{abstract}

Кључне речи: Геолошко-економски модели, стратегијско планирање, рудна лежишта, минерална економија, минерални сектор.

\section{1. УВОД}

Базична материјална производња у различитим привредним гранама земље у великој мери је стратегијски зависна од производње бројних минералних сировина. Одређене металичне, неметаличне или енергетске минералне сировине или минералне компоненте у њиховом саставу, директно или индиректно се користе у бројним

How to cite: Tošović, R. (2020). Strategic Implementation of Geological-Economic Monitoring to Ensure Safer Production and Operating Conditions for the Mineral Sector Enterprises. In Proceedings of the 25th International Scientific Conference Strategic Management and Decision Support Systems in Strategic Management. https://doi.org/10.46541/978-86-7233-386-2_32 
производним процесима добијања различитих производа. С обзиром на ширину утицајног дијапазона зависности, привредно, економски и стратегијски је веома значајно пословање предузећа, која се баве минералном производњом. Успешно функционисање предузећа минералног сектора земље и производње одређених минералних сировина у појединачним предузећима, директно је повезано са деловањем одређених: (a) макроекономских и (б) микроекономских фактора. Макроекономски фактори, који, са становишта предузећа као производног субјекта, представљају спољне факторе, превасходно се односе на опште тржишне услове, а директно одражавају преко конкуренције, понуде и тражње за одређеним минералним сировинама. Појединачна предузећа минералног сектора на њих не могу битније утицати, већ им се, кроз адекватне пословне одлуке, морају прилагођавати. Као веома илустративан пример у актуелним условима се може навести утицај глобалних тржишних кретања, привредних ограничења, трговачких редукција и производних проблема услед проглашене пандемије вируса COVID19. Микроекономски фактори, с друге стране, представљају факторе интерног типа, који директно зависе од самог предузећа. Степен и успешност ангажовања и коришћења одговарајућих производних ресурса предузећа кључна је за његову производну и пословну успешност, везану за геолошко истраживање, експлоатацију, припрему, прераду и тржишну валоризацију минералне сировине. Постојећи транзициони и економски трендови економике минералних ресурса и економике предузећа усмерни су на тржишно оријентисане принципе и критеријуме планирања и реализације производње, тржишту потребних минералних сировина (Tošović, 2017a). Сходно томе у предузећима минералног сектора посебно долази до изражаја потреба интензивнијег увођења и брже примене ефикасног геоменаџмента (Тошовић\&Миловановић, 2007; Тошовић, 2010a), затим стратегијског менаџмента (Тошовић, 2016а), стратегијског маректинга (Тоšоvić, 2010б), концепта одрживог развоја (Tošović, 2012), као и неопходност целовитог проучавања, сагледавања и тржишног дефинисања кључних геолошко-економских карактеристика рудног лежишта (Тошовић, 2006) са предметном минералном сировином.

Турболентност тржишних кретања и променљивост економских услова производње и продаје минералних сировина условљава посебну потребу примене економских метода и алата у планирању и реализацији минералне производње. Међу овим методама посебно значајно место заузима геолошко-економска метода оцене, којом се врши систематично распоређивање и анализа бројних фактора и показатеља, који утичу на исплативост и степен исплативости производње минералних сировина. Економска оцена лежишта, које је предмет привредне активности предузећа, развијана и примењивана у земљама са развијеним минералним економијама (Rudenno, 2012; Rundge, 1998; Torries, 1998; Wellmer et al, 2010; Cehlar et al, 2014), значајно је утицала на унапређење домаће економске геологије (Јанковић\&Миловановић, 1985) и савремене праксе геолошко-економске оцене домаћих минералних лежишта (Tošović, 2016б). Комплексна геолошко-економска оцена рудних лежишта у Србији у новијем периоду је значајно унапређена и модернизована, што је, у домаћим условима, између осталог, резултирало увођењем и развојем тржишних критеријума геолошко-економске оцене лежишта (Тошовић, 2006) и третирање лежишта, не само као геолошке, већ првенствено економске категорије. Кроз прикупљање, анализу и приказ фактора и сета показатеља геолошко-економске оцене (Тошовић, 2006), значајно је олакшана систематизација, обрада, интерпретација и финални приказ бројних геолошких и економских информација (Tošović, 2014, 2016 в) везаних за рудно лежиште као стратегијски значајну основу пословања предузећа минералног сектора. Основни циљ овог рада је да истакне место, улогу и значај геолошко-економског мониторинга у праћењу геолошко-економских карактеристика рудног лежишта, које су значајне за пословну стратегију и политику предузећа, као и циљно побољшање сигурности, услова и ефеката пословања предузећа минералног сектора земље.

\section{2. ЕКОНОМСКА ОЦЕНА И ГЕОЛОШКО-ЕКОНОМСКИ МОНИТОРИНГ}

Предузећа минералног сектора у савременом динамичном и турболентном тржишном окружењу, у непосредном обезбеђењу потребних услова пословања и специфичном производном процесу, испољавају зависност од низа фактора, међу којима се нарочито могу издвојити следећи: (а) тржишни услови, међу којима је посебно важна тржишна цена минералне сировине; (б) минералне резерве у лежишту, односно квантитативни аспекат резерви; (в) квалитет минералне сировине, односно квалитативни аспекат резерви и (г) профитабилност, односно исплативост истраживања минералних резерви и производње минералних сировина. Први фактор припада групи екстерних, везује се за макроекономски ниво, а на њега предузеће нема утицаја и мора му се прилагођавати. Преостала три фактора припадају групи интерних, везују се за микроекономски ниво, а на њих предузеће има директан утицај и мора их, одговарајућом пословном активношћу, на одређен начин обезбедити. Специфична је позиција четвртог фактора, који је делом везан за први екстерни фактор, а делом за друга два интерна фактора. Посебно је илустративан пословни случај када предузеће при истим интерним факторима и обезбеђеним елементима производног процеса, у једном тренутку производње обезбеђује профитабилност, а након наглог пада цене минералне сировине на берзи, може директно заћи у зону угрожавања профитабилног рада, па чак и остваривања губитака. Предузећа минералног сектора отуда циљно морају посебну пажњу посветити стратегијском обезбеђењу услова повећања сигурности производње минералних производа, по различитим стратегијским, менаџерским и нарочито економским аспектима. Са економског становишта од фундаменталног значаја у стратегијском планирању геолошких истраживања, експлоатације, припреме и прераде минералне 
сировине је примена методе геолошко-економске оцене предметних минералних резерви, односно минералног лежишта као основне економске категорије.

Савремена оцена минералних резерви, у светској пракси минералне економије, укључује различите врсте и типове оцена, које омогућују оцењивање са различитих аспеката, различитог степена сложености и коначног израза оцене (Tošović, 2017a). Као најчешће примењивани могу се навести следећи типови оцена: Геолошка оцена, Геолошко-економска оцена, Техничко-економска оцена, Економска оцена, Технолошка оцена, Индустријска оцена, Прифизибилити студија, Физибилити студија, Рударски извештај, Геоеколошка оцена и др. У домаћим условима вишедеценијског развоја минералне економије и функционисања минералног сектора Србије, у склопу познате Београдске школе економске геологије, на Катедри економске геологије Рударскогеолошког факултета Универзитета у Београду, развијана је комплексна и свеобухватна геолошко-економска оцена (Tošović, 2017a). Ова врста свеобухватне и интегралне оцене, представља специфичну експертску оцену (Tošović, 2017г), која ce, суштином проблематике и приступа, налази у пресеку две карактеристичне сфере. Она комбинује основну геолошку сферу познавања минералних лежишта, са економском сфером, као тржишним вредновањем предметних минералних сировина. У коначном резултату интегративног повезивања различитих података и информација од прве фазе геолошких истраживања, преко експлоатације, технолошке припреме и прераде, до добијања коначног тржишног производа у виду ровне руде, оплемењеног концентрата, истопљеног метала или готовог минералног производа добија се економска оцена, као мера профита, који се од минералне сировине може остварити (Tošović, 2017б, 2018).

Геолошко-економска оцена појединачног минералног лежишта, у практичном смислу представља посебну врсту менаџерског алата, веома значајног за доношење неопходних стручних и менаџерских одлука значајних за пословање предузећа минералног сектора. За конкретну примену геолошко-економског мониторинга појединих елемената геолошко-економске оцене есенцијално је битан привремени карактер оцене. Он заправо представља веома значајан полазни принцип оцене, по коме се аналитички одређене појединачне вредности и величине, у склопу геолошко-економске оцене, односе на одређени временски пресек важења дефинисаних фактора и показатеља оцене. Са променом временског пресека долази до одређених промена појединих фактора и показатеља, што се директно одражава и на економску оцену минералних резерви и економске ефекте производње у предузећу. На најједноставнији начин, ова привременост и променљивост, може се илустровати кроз тржишну цену минералне сировине, која се, у зависности од кретања на берзи, може значајно мењати и тако директно утицати на резултате пословања предузећа. Наведено изискује потребу да се врши мониторинг свих значајних фактора и показатеља оцене, како би се у сваком тренутку пословања предузећа могле пратити вредности предметних резерви, економски и финансијски резултати пословања. При томе можемо издвојити: (а) мониторинг фактора економске оцене и (б) мониторинг показатеља економске оцене. Геолошко-економски карактер мониторинга проистиче из геолошко-економске природе рудног лежишта и чињенице да се економска вредност резерви и економски и финансијски ефекти производње у предузећу минералног сектора базирају на геолошким, односно минералним резервама као основи. Периоди мониторинга треба да одговарају седмичном, месечном и кварталном нивоу. По истим временским пресецима праћени елементи се могу користити и за сагледавање утицаја на остваривање производње и финансијских ефеката пословања предузећа. То између осталог укључује и преиспитивање раније донетих производних и пословних одлука и њихову евентуалну корекцију у зависности од кретања и последичног утицаја позитивне или негативне промене. Неопходност спровођења геолошко-економског мониторинга се веома добро може илустровати примером садашњих тржишних, производних и привредно-економских проблема, насталих услед пандемије вируса COVID19. Oбим производње, као и потрошње бројних металичних, неметаличних, као и енергетских минералних сировина, од почетка пандемије значајно је смањен. То је према закону понуде и тражње неминовно условило и значајан пад цена свих минералних сировина, уз перспективу њиховог даљег пада и веома негативног утицаја на производне и пословне резултате предузећа минералног сектора. Неопходно праћење, квантификовање, изражавање и анализа промена кључних фактора и показатеља економске оцене, могу се успешно реализовати кроз благовремени и одговарајући геолошко-економски мониторинг.

\section{3. АКТИВНОСТ МОНИТОРИНГА ФАКТОРА ЕКОНОМСКЕ ОЦЕНЕ}

Геолошко-економска оцена минералних ресурса, кроз системско-аналитички приступ, може се представити као хијерархијски највиши систем, који се састоји од подсистема изражених кроз конкретне факторе, а то су (Tošović, 2006, 2018; Јанковић\&Миловановић, 1985): (1) Металогенетски; (2) Геолошки; (3) Техничко-експлоатациони; (4) Технолошки; (5) Тржишни; (6) Регионални; (7) Социјално-политичко-економско-стратегијски; (8) Геоеколошки и (9) Законодавно-правни фактори. Ови фактори, ширином лепезе факторске анализе предметних података о минералном лежишту, пружају могућност комплетне анализе релевантних података значајних за пословање предузећа, које врши валоризацију минералне сировине. При томе се, у делу који се тиче материјалне производње минералних сировина, као посебно значајан нарочито може издвојити мониторинг геолошких, техничкоексплоатационих и технолошких фактора. У делу који се тиче финансијског аспекта производних резултата нарочито се може издвојити мониторинг тржишних фактора. У садашњим тржишним, производним и привредно-економским проблемима насталим услед пандемије вируса COVID19, као посебно значајан се може издвојити мониторинг техничко-експлоатационих фактора, као производних фактора, као и мониторинг 
тржишних фактора. Геолошко-економски мониторинг фактора се, због претежно дескриптивне и обимне факторске анализе, оперативно усмерава на мониторинг појединачних показатеља економске оцене.

\section{4. АКТИВНОСТ МОНИТОРИНГА ПОКАЗАТЕЉА ЕКОНОМСКЕ ОЦЕНЕ}

Полазну геолошко-економску аналитичку активност, кроз коју се обрађују претходно наведени фактори геолошко-економске оцене, прати други, виши и експлицитнији аналитички корак. Из базичне стручне анализе сваког од наведених специфичних фактора, изводе се појединачни показатељи оцене, као елементи значајни за потпуност приказа ових факторских подсистема, а обухватају три основна сета показатеља, и то (Tošović, 2006, 2018; Јанковић\&Миловановић, 1985): (1) Сет натуралних; (2) Сет вредносних и (3) Сет синтетских показатеља. Мониторинг вредносних и синтетских показатеља је посебно тржишно значајан, како за рудно лежиште, тако и за предузеће. Њихово повезивање са натуралним показатељима, одлучујуће је за праћење могућности даљег рентабилног/профитабилног искоришћења минералних резерви. Овај мониторинг је важан, како за израду планских докумената везаних за минералне резерве, тако и за годишње и вишегодишње планове производње и планове пословања предузећа минералног сектора. Осим тога посебно су значајни за анализу успешности планирања и праћење кретања производних фактора везаних за минералне резерве и тржиште минералних сировина. У садашњим тржишним, производним и привредно-економским проблемима насталим услед пандемије вируса COVID19, као посебно значајан може се издвојити мониторинг сета вредносних и сета синтетских показатеља.

\section{1. Активност мониторинга сета натуралних показатеља}

Натурални показатељи економске оцене су изражени у физичким, односно натуралним јединицама мере (нпр. проценти, метри, тоне, године и др.). Разликују се два подсета натуралних показатеља, и то (Тošović, 2006, 2018; Јанковић\&Миловановић, 1985): (а) подсет натуралних показатеља у ужем смислу и (б) подсет натуралних показатеља у ширем смислу. Први су једноставнији, лакше се прорачунавају или мере. Други су сложенији и често се прорачунавају комбиновањем натуралних показатеља у ужем смислу и вредносних показатеља, а знатно су бројнији.

У натуралне показатеље у ужем смислу, као најважнији појединачно спадају: (1) Геолошке резерве минералних сировина (руде и корисне компоненте); (2) Средњи садржај корисне компоненте; (3) Средњи садржај штетних и непожељних компоненти; (4) Средња дебљина рудног тела; и (5) Средња дебљина јалових прослојака.

У натуралне показатеље у ширем смислу, као најважнији појединачно спадају: (1) Минимални економски садржај корисне компоненте; (2) Минимални садржај откопавања (гранични садржај); (3) Минималне геолошке резерве у лежишту и појединим рудним телима; (4) Минимална дебљина рудних тела и лежишта; (5) Минимална дебљина јалових прослојака и ванбилансних делова; (6) Оптимална и максимална дубина експлоатације лежишта; (7) Коефицијент рудоносности; (8) Максимални садржај штетних и непожељних компоненти; (9) Минимални садржај искористивих пратећих компоненти; (10) Губици при експлоатацији, припреми и примарној преради минералне сировине; (11) Разблажење корисне компоненте при експлоатацији; (12) Експлоатационе резерве минералне сировине, односно корисне компоненте; (13) Капацитет рудника, постројења за припрему и постројења за прераду; (14) Век експлоатације лежишта; (15) Садржај корисних и штетних компонената у концентрату; (16) Садржај корисних и штетних компонената у примарном финалном производу; (17) Степен искоришћења код припреме руда и прераде руда/концентрата; (18) Утрошак руде за 1 т концентрата; (19) Утрошак концентрата за 1 т примарног (финалног) производа; (20) Рок повраћаја (реакумулације) уложених средстава; (21) Средњи и гранични коефицијенат раскривке; и (22) Стопа рентабилности у односу на рудник, постројење за припрему и примарну прераду.

Мониторинг наведених натуралних показатеља је од посебног значаја за доношење одговарајућих пословних одлука везаних за минералне резерве, квалитет минералне сировине, капацитет производње и век експлоатације. При томе, нарочито треба имати у виду да за различите металичне, неметаличне и енергетске минералне сировине, предметни показатељи имају своје специфичности и сходно тим специфичностима потребу приказа и мониторинга вредности појединачних показатеља из комплетног сета. На основу мониторинга наведених натуралних показатеља могу се надаље кориговати, планирати, пратити и реализовати одговарајући натурални плански елементи производње у пословној години и планирати и доносити потребне пословне одлуке. У садашњим тржишним, производним и привредно-економским проблемима насталим услед пандемије вируса COVID19, као посебно значајан се може издвојити мониторинг натуралних показатеља у ширем смислу претходно наведених под бројевима 1, 2, 3, 20 и 22. Због пада цене минералне сировине на берзи, директно се смањује минимални економски садржај корисне компоненте у лежишту, што значи да се сиромашнија руда економски не исплати за даљу експлоатацију. То условљава и смањење укупних резерви, које ће се експлоатисати, а тиме и смањење века експлоатације рудника. Због лошијих финансијских резултата, рок повраћаја уложених средстава се повећава, а стопа рентабилности предузећа се смањује. 


\section{2. Активност мониторинга сета вредносних показатеља}

Вредносни показатељи економске оцене су изражени у вредносним, односно новчаним јединицама, а као најважнији се издвајају следећи (Тošović, 2006, 2018; Јанковић\&Миловановић, 1985): (1) Трошкови геолошких истраживања 1 т резерви одређених категорија и укупни трошкови истраживања; (2) Укупне потребне и уложене инвестиције у истраживање, изградњу рудника, постројења за припрему и постројења за примарну прераду; (3) Специфичне инвестиције по 1 т руде, концентрата и финалног производа; (4) Цена коштања 1 т руде, концентрата и финалног производа; (5) Тржишна цена руде, концентрата и финалног производа (текућа и прогнозна); (6) Акумулација, односно добит по 1 т руде, концентрата или финалног производа; (7) Трошкови транспорта; и (8) Рентабилност.

Мониторинг наведених показатеља је посебно важан за трошковне и инвестиционе показатеље, као и посебно практично значајан показатељ цене коштања минералне сировине. Она обухвата детаљну калкулацију са свим потребним трошковним елементима у разним фазама третирања. Са променама улазних елемената последично долази до промене и цене коштања. Мониторинг релације са тржишном ценом, може омогућити корекцију планираног економског ефекта производње и потпунијег дефинисања степена рентабилности и економичности предметне производње минералне сировине у предузећу. У крајњој линији утиче и на могуће корекције финансијског резултата пословања, а у екстремним случајевима евентуалног пада тржишне цене испод цене коштања, и до остваривања губитака у производњи. У садашњим тржишним, производним и привредноекономским проблемима насталим услед пандемије вируса COVID19, као посебно значајан се може издвојити мониторинг вредносних показатеља претходно наведених под бројевима 5, 6 и 8. Предметно обухвата смањење тржишне цене минералних производа, што се због погоршања финансијског резултата пословања директно одражава на смањење акумулације, као и смањење рентабилности. Нпр. Цена бакра на берзи (Тошовић, 2020) је ca 5.737 USD/t од 14.02.2020. год, смањена на 4.855 USD/t од 20.03.2020. год, а потом на 4.617 USD/t од 23.03.2020. год. Још је илустративнија промена цене нафте (Тошовић, 2020), нпр. типа Уралс, чија цена је ca 53,05 USD/bbl од 14.02.2020. год, смањена на 19,90 USD/bbl од 19.03.2020. год, а потом на 18,30 USD/bbl од 01.04.2020. год. При томе наравно треба имати у виду да су у питању осцилације у кратком временском периоду, али које ће уз остала неповољна тржишна кретања услед пандемије, дугорочно утицати на слабије производне и финансијске ефекте предузећа произвођача ових минералних сировина.

\section{3. Активност мониторинга сета синтетских показатеља}

Синтетски показатељи економске оцене су најсложенији показатељи, који се често изражавају системом показатеља. Обухватају показатеље вишег реда, чије одређивање укључује претходно одређене натуралне и вредносне показатеље, а као најважнији се издвајају следећи (Тošović, 2006, 2018; Јанковић\&Миловановић, 1985): (1) Вредност лежишта и резерви без узимања временског фактора у обзир; (2) Економске класе резерви на бази потенцијалног профита (економска класификација резерви); (3) Вредност лежишта одређена динамичким методама оцене (са узимањем временског фактора у обзир) - показатељи добијени прорачуном NPV и IRR, и изведени индикатори; и (4) Цена 1 т истражених резерви.

Мониторинг наведених показатеља је посебно важан за планске и инвестиционе показатеље, нарочито за вредност лежишта, која се изражава кроз износ нето профита, који се може остварити у пословању предузећа, а на основу мониторингом констатованих експлоатационих минералних резерви. И у домаћој пракси минералне економије у Србији, за свако минерално лежиште се врши одређивање вредности лежишта са и без узимања временског фактора у обзир. При томе се посебно економски релевантним сматра вредност одређена NPV и IRR методом, нарочито у случају дужег века експлоатације предметних минералних резерви. Мониторинг показатеља, који се појављу као улазне прорачунске вредности за NPV и IRR, може довести до потребе њиховог кориговања, што има значајне последице у погледу сагледавања реалних економских ефеката производње и пословања предузећа минералног сектора. У садашњим тржишним, производним и привредно-економским проблемима насталим услед пандемије вируса COVID19, значајан је мониторинг нарочито прва три наведена показатеља. Пад тржишне цене минералне сировине, уз потенцијални проблем повећања трошкова производње, који се такође појављује, битно условљава самањивање економске вредности минералних резерви у лежишту, иако су оне у квантитативном изразу остале исте или приближно исте. Наведено доводи у питање и профитабилност рада, као и потребу улагања посебних финансијских средстава у истраживање нових минералних резерви, без претходног сагледавања сада расположивих производних капацитета и производних количина по појединим минералним врстама.

Геолошко-економски мониторинг у предузећима минералног сектора треба да реализује стручно-експертски тим у коме треба да учествују стручњаци геолошког, рударског, технолошког и економског профила. Свако у свом домену, у оквиру мониторинга, треба да одради два нивоа монтиоринга, и то: (а) базични мониторинг и (б) аналитички мониторинг. Кроз полазни базични мониторинг стручњаци треба да прате: (i) актуелно стање фактора економске оцене, које се претежно изражава дескриптивно; и (ii) вредности показатеља економске оцене, које се изражава преко нумеруса. Кроз аналитички мониторинг стручњаци треба да анализирају: (i) промену показатеља у односу на ранију мониторску вредност, нарочито кроз примену компаративне анализе; и (ii) утицај промене показатеља на производни и пословни резултат предузећа. У коначном закључном стручном делу мониторинга, 
потребна је припрема стручних елемената као основе за доношење одговарајућих менаџерских, производних, планских и пословних одлука у предузећу. На тај начин се геолошко-економски мониторинг појављује у директној функцији омогућавања сигурнијих услова производње минералних сировина и минералних производа, као и успешнијег пословања предузећа минералног сектора. У садашњим тржишним, производним и привредноекономским проблемима насталим услед пандемије вируса COVID19, геолошко-економски мониторинг је неопходан, како краткорочно, тако и стратегијски дугорочно, јер ће омогућити прилагођавање производних и пословних одлука примерено објективним ограничавајућим околностима, смањењу производње и потрошње, затим паду тржине цене минералног производа и смањењу профита из тржишне валоризације предметне металичне, неметаличне или енергетске минералне сировине.

\section{5. ЗАКЉУЧАК}

Базична материјална производња у различитим привредним гранама земље у великој мери је стратегијски зависна од производње бројних минералних сировина. Турболентност тржишних кретања и променљивост економских услова производње и продаје минералних сировина условљава потребу примене економских метода и алата у планирању и реализацији минералне производње. Међу овим методама посебно значајно место заузима геолошко-економска метода оцене, којом се врши систематично распоређивање и анализа бројних фактора и показатеља, који најшире утичу на исплативост производње минералних сировина у предузећима минералног сектора.

Геолошко-економска оцена минералног лежишта, представља посебну врсту менаџерског алата, веома значајног за доношење неопходних стручних и менаџерских одлука за стратегијско пословање предузећа минералног сектора. Полазећи од принципа привременог карактера економске оцене, постоји неопходност мониторинга свих значајних фактора и показатеља оцене. Она треба да омогући, током пословања предузећа, актуелно праћење вредности минералних резерви и нарочито економских и финансијских резултата пословања. При томе се издвајају мониторинг: (i) фактора економске оцене и (ii) показатеља економске оцене.

Примена геолошко-економског мониторинга у предузећима минералног сектора је стратегијски веома значајна ради реалног праћења геолошко-економског значаја лежишта, затим економског ефекта предметне производње и стварања профита из минералних сировина, а на основу геолошких елемената производног процеса и вредносних показатеља везаних за минералне сировине. Иста је веома важна за израду планских докумената везаних за минералне резерве, затим за годишње и вишегодишње планове производње, планове успешности пословања предузећа минералног сектора и одговарајуће пословне одлуке.

Геолошко-економски мониторинг у предузећима минералног сектора треба да реализује стручно-експертски тим стручњака геолошког, рударског, технолошког и економског профила. При томе треба обухватити два нивоа монтиоринга, и то: (i) базични и (ii) аналитички мониторинг. Кроз базични мониторинг треба пратити: (i) актуелно стање фактора економске оцене; и (ii) вредности показатеља економске оцене. Кроз аналитички мониторинг треба анализирати: (i) промену показатеља у односу на ранију мониторску вредност, применом компаративне анализе; и (ii) утицај промене показатеља на производни и пословни резултат предузећа.

Интензивнију стратегијску и аналитичку активност на примени геолошко-економског мониторинга, треба спроводити на нивоу појединачног предузећа, појединачног лежишта, као и на нивоу минералног сектора. Исто треба да обезбеди сигурније предуслове за успешну производњу и економско пословање предузећа носилаца активности истраживања, експлоатације и валоризације предметне минералне сировине у склопу решавања практичних проблема, потешкоћа и ограничења, као и успешнијег функционисања минералне економије у предстојећем периоду друштвеног, привредног и економског развоја земље.

\section{РЕФЕРЕНЦЕ}

Cehlar, M., Jurkasova, Z., Behun, M., Szabo, S. (2014). Model of mineral deposits economic evaluation. SGEM2014 Conference Proceedings, 14th International Multidisciplinary Scientific GeoConference SGEM 2014, Book 1, Vol. 3 , pp. 387-394.

Јанковић, С., Миловановић, Д. (1985). Економска гелогија и основи економике минералних сировина. Катедра Економске геологије, РГФ, 403 пп., Београд.

Rudenno, V. (2012). The Mining Valuation Handbook: Mining and Energy Valuation for Investors and Management. Wrightbooks; 4 edition, 624 pp..

Rundge, I. (1998). Mining Economics and Strategy. Society for Mining Metallurgy \& Exploration, 1 edition, Littleton, 316 pp., Colorado.

Torries, F.T. (1998). Evaluating Mineral Projects: Applications and Misconceptions. Society for Mining Metallurgy \& Exploration, Littleton, 172 pp., Colorado. 
Tošović, R. (2018). Practical Application of Indicators of the Economic Evaluation of Mineral Reserves in Business Operations of the Mineral Sector Companies. Novi ekonomist, Vol 12(2), Year XII, 2018.

Тошовић, Р. (2020). Анализа промене цена минералних сировина на берзи у периоду почетка пандемије COVID19 вируса. Непубликован материјал, 12 пп., Београд.

Tošović, R. (2017a). Geological-economic Modelling in Current Conditions of Ore Deposit Exploration. 7 th Balkanmine congress - Proceedings, Prijedor 2017, pp. 69-74, Book 2, Prijedor.

Tošović, R. (20176). Economic Evaluation of Small Deposits in the Applicable Function of Business Decision in Mineral Economy, International Journal of Business and Management Invention (IJBMI), vol. 6, no. 9, pp. 59-63.

Тошовић, Р. (2016а). Стратегијске смернице развоја и ефикасност пословања минералног сектора. Зборник радова XXI Интернационалног научног скупа СМ 2016 Стратегијски менаџмент и системи подршке одлучивању у стратегијском менаџменту, Тема скупа Стратегијски менаџмент - детерминанте развоја и ефикасност пословања, Економски факултет Суботица, пп. 1184-1193, (CD издање), Суботица.

Tošović, R. (20166). General review of the genetic and geological-economic modeling of the mineral deposits of Serbia. International Journal of Research - Granthaalayah, Vol. 4, No. 6, pp. 38 - 45, 2016.

Тошовић, Р. (2016в). Геолошко-економско моделирање лежишта у савременој инжењерској пракси. Зборник II Рударско-геолошког форума са међународним учешћем, Рударски факултет Приједор Универзитета у Бањој Луци, пп. 258-266, Приједор.

Tošović, R. (2016r). Expert economic evaluation of mineral resources in the function of environmental protection. International Journal of Research - Granthaalayah, Vol. 4, No. 5, pp. $106-114$.

Tošović, R. (2014). Practical Aspects of Economic Evaluation of Mineral Projects in Investment Decision Making. Proceeding of 17th International Conference Dependability and Quality Management ICDQM-2014, pp. 497-504, Belgrade.

Tošović, R. (2012). Economics of Mineral Resources, Mineral Reserves and Mineral Raw Materaials in the Concept of Sustainable Development. International Scientific Conference on Innovative Strategies and Technologies in Environment Protection, Belgrade, 64-65, Belgrade.

Tošović, R. (2010a). Management in Modern Conditions of Serbian Mineral Economy, MISKO 10, pp. 411-434, Belgrade.

Tošović, R. (2010б). Marketing Management in Current Conditions in Mineral Sector. XVI Serbian Geological Congress, Beograd, 241-247, Belgrade.

Тошовић, Р., Миловановић, Д. (2007). Геолошко-економска оцена у функцији геоменаџерских активности. Техника, Руд.,Геолог.и Метал., LXII, 5, пп. 9-16, Београд,.

Тошовић, Р. (2006). Геолошко-економско моделирање полиметаличног лежишта Рудник. Катедра економске геологије Рударско-геолошког факултета, Посеб. изд. Бр. 8, 226 пп. , Београд.

Wellmer, F.W., Dalheimer, M., Wagner, M. (2010). Economic Evaluations in Exploration. Springer; 2nd edition, 264 pp. 


\title{
STRATEGIC IMPLEMENTATION OF GEOLOGICAL-ECONOMIC MONITORING TO ENSURE SAFER PRODUCTION AND OPERATING CONDITIONS FOR THE MINERAL SECTOR ENTERPRISES
}

\begin{abstract}
The market turbulence of the ways and conditions of business of the mineral sector enterprises, especially the connection with the mineral reserves and their market specificities, requires a special strategic approach in planning, monitoring and realization of the business. The security of mineral reserves, their commercial and national profitability, as well as the variability of quality, are quite pronounced problems of production of certain mineral products related to metallic, non-metallic and energy mineral resources. The main objective is to provide conditions for increasing the security of production of mineral resources and corresponding mineral products, given the constant changes in the market of mineral resources, and on this basis, more successful business of enterprises in the mineral sector of the country, while maintaining competitiveness. In providing up-to-date data and information, the application of the method of geological-economic evaluation of mineral reserves, with the appropriate methodological structure of factors and indicators of evaluation, is of particular importance. Its application in different weather sections and changes in the mineral market leads to the definition of practically very applicable and useful geological-economic monitoring. It solves the problem of the actuality and validity of all production data relevant to the mineral raw material concerned and the realization of the production process in the company. Geological-economic monitoring, with the use of the method of comparative analysis, becomes an important strategic, managerial and economic tool, which enables safer conditions of production of mineral raw materials and mineral products, as well as more successful business of the companies of the mineral sector.
\end{abstract}

Key words: Geological-economic monitoring, strategic planning, mineral deposits, mineral economy, mineral sector. 